\title{
傾斜水路の跳水特性に対する気泡混入射流の影響 \\ EFFECT OF AERATED INFLOWS ON CHARASTERISTICS OF HYDRAULIC JUMPS IN SLOPING CHANNELS
}

 \\ Jun KOBAYASHI, Youichi YASUDA, and Iwao OHTSU \\ 1 学生会員 修(工) 日本大学大学院 理工学研究科土木工学専攻（广101-8303 東京都千代田区神田駿河台 1-8) \\ 2 正会員 博(工） 日本大学助教授 理工学部土木工学科（广101-8303 東京都千代田区神田駿河台 1-8） \\ 3フェロー会員 工博 日本大学教授 理工学部土木工学科（广101-8303 東京都千代田区神田駿河台 1-8)
}

\begin{abstract}
Many researchers have investigated characteristics of the hydraulic jump in sloping channels, but the effect of aerated inflow on flow characteristics of the hydraulic jump has not been shown. This paper presents the effect of aerated inflow on flow characteristics of hydraulic jumps in steep sloping channels (i.e., 30 and 55 degrees). The experimental investigation reveals that the jump length is affected by the air-concentration of the aerated inflow. The length of the jump has been formulated. By considering the air-concentration in the jump, the sequent depth ratio of the jump in sloping channels has been obtained on the basis of the momentum equation.
\end{abstract}

Key Words: Sloping Channel, Energy Dissipator, Stilling Basin, Hydraulic Jump, Sequent depth, Aerated Inflow

\section{1. まえがき}

堰やダムなどの落差を伴う構造物から流下寸る高速流 のエネルギーを減勢させる方法として, 構造物下流側の 減勢池で跳水を形成させることが一般的である.また， ダムや垵から越流する高速流において多量の気泡混入が 生じている場合が多く見られる．しかしながら，流入射 流の気泡混入による跳水特性への影響, 例えば跳水の流 況，跳水内部の流速特性およひ跳水長一の影響について はほとんど解明されていない，これは，従来の跳水現象 の実験的研究 1) 4 において，模型規模では流入射流に気 泡が混入されないためである. 流入射流に気泡が混入さ れた場合の研究についてはRajaratnam ${ }^{11} に よ る$ 水平水路 の自由跳水を対象に，跳水上下流端の水深間の関係を検 討した研究があるにすぎない. 気泡混入射流による跳水 特性への影響を知ることは, 河川横断構造物の下流側の 減勢池を設計する上で重要である。

最近, 著者らは水路傾斜角度 $\theta=30^{\circ}, 55^{\circ}$ の傾斜水路に おいて射流から常流一遷移寸る流れを対象に，模型規模 でも流入射流に気泡が混入される工夫を行い，遷移部の

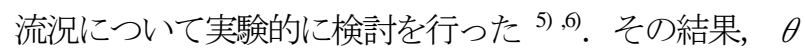
$=30^{\circ}, 55^{\circ}$ で下流水深 $h_{d}$ が大きく $h_{d} / h_{2}>3.0$ の場合 $\left(h_{2}\right.$ は
水平水路上の自由跳水の対応水深 [図-1参照]), 流入射流 に気泡が混入されていないとき, 顕著な表面渦は形成さ れず, 広範囲にわたって循環流(逆流)が形成されるように なる. 流入射流に多量の気泡が混入すると, 遷移部に多 量の気泡が混入し, 気泡の浮力効果によって水路床に沿 って流入した高速流が短区間で水面に向かって上昇し, 常に顕著な表面渦が形成されることを見出した5).ここで は射流から常流一遷移寸る流れの流況において, 顕著な 表面渦が形成される場合と広範囲に循環流が形成される 場合の両者共に跳水と呼ぶことにする.

流入射流の気泡混入の有無によって傾斜水路における 表面渦の形成条件, 跳水の流況，あるいは跳水長が大き く変化することから, 跳水特性に対する気泡混入射流の 影響を検討することが重要である.

本研究では傾斜水路において射流加常流一遷移寸る 流れを対象とし, 流入射流の気泡混入量の変化による跳水 長の変化を明らかにした. また, 流入射流に十分気泡が混 入された場合を対象に, 流入射流およひ跳水部における気 泡混入の影響を考慮した運動量方程式から, 跳水上下流端 の水深間の関係ついて明らかにした. また, 跳水上下流端 の水深間の関係について, 流入射流に気泡が混入された場 合と気泡が混入されない場合との違いを示した. 


\section{2. 実験}

本実験では，水路傾斜角度 $\theta=30^{\circ}, 55^{\circ}$ の長方形断面 傾斜水路における跳水を対象とし(図一1), 表一1 に示寸 実験条件のもとて跳水特性について検討を行った. 表一1 中の跳水始端での断面平均された気泡混入率 $C_{\text {mean }}{ }^{7}$, 流 入射流のフルード数 $F_{1}$ および $h_{2}$ はそれぞれ(1)，(2)，(3) 式によって算出される.

$$
\begin{aligned}
& C_{\text {mean }}=\frac{1}{y_{0.9}} \int_{0}^{y_{0.9}} C d y \\
& F_{1}=\frac{V_{1}}{\sqrt{g d_{1} \cos \theta}}=\frac{q_{w}}{\sqrt{g d_{1} \cos \theta} d_{1}} \\
& h_{2}=\frac{d_{1}}{2}\left(\sqrt{8 F_{1}^{2} \cos \theta+1}-1\right)
\end{aligned}
$$

ここにC $C$ は水路底面からの垂直距離 $y$ における時間平均 された気泡混入率(=気泡混入量 / (気泡混入量+水の量 $)$, $d_{1}$ は水の夕に換算した流入射流の水深 $\left(d_{l}=\left(1-C_{\text {mean }}\right) y_{0.9}\right)$, $q_{w}$ は水のみの単位幅流量 $\left(q_{w}=Q / B ; B\right.$ は水路幅, $Q$ は 水のみの流量), $V_{l}$ は $d_{l}$ から求めた断面平均流速 $\left(V_{l}=q_{w} / d_{l}\right), y_{0.9}$ は $C=0.9$ となる $y$ の值を示している. な お， $q_{w}$ は水路下流側に設置された全幅㘿から測定した流 量 $Q$ より算定した. また, 跳水始端において気泡混入率 の分布を水路横断方向に 5 箇所測定し, 各測定断面の平 均された気泡混入率を求め, それらを平均して $C_{\text {mean }}$ およ びd $d_{1}$ 定めた.

レイノルズ数 $R_{e}\left(R_{e}=V_{l} d_{1} / \nu=q_{w} / \nu ; \nu\right.$ は水の動粘性 係数) が $30000 \lesssim R_{e} \lesssim 70000$ の範囲で実験を行った場合, 滑面傾斜面上の射流には気泡が混入されないため，射流 中に気泡を混入させるために階段状水路 ${ }^{8,9}$, 利用した. また, 流入射流の断面平均された気泡混入率 $C_{\text {mean }}$ は流量 およひ階段状水路のステップの高さを変化させて調整し た. ただし，階段状水路の形状が跳水の流況およひ跳水 内部の流速特性に影響しない上うに跳水始端直上流側か ら水路接合部までの水路傾斜面を滑面水路とした. 図一2 に示されるように，流入射流の気泡混入率の分布形状は diffusion model 》りよって示された気泡混入率の分布と同 様な形状となり，ステップの形状による気泡混入率の分 布形状の違いは認められない.

跳水内部の水路底面近傍では気泡がほとんど存在しな かったため，底面圧力の測定はピト一管の静圧管を用い た．なお，水路床に設置した圧力取り出し孔を用いた場 合とピト一管の静圧管を用いた場合とで圧力の測定値は ほとんど同じ值を示すことを実験的に確認している。 ま た，流入射流における断面平均された気泡混入率 $C_{\text {mean }}$ お よび跳水内部における気泡混入率の測定には点電極型ボ イド率計を用いた（採取時間 60s，採取間隔 $5 \mathrm{~ms}$ ).
表-1 実験条件

\begin{tabular}{|c|c|}
\hline$\theta=30^{\circ}$ & $\theta=55^{\circ}$ \\
\hline $0 \leqq C_{\text {mean }} \leqq 0.38$ & $0 \leqq C_{\text {mean }} \leqq 0.55$ \\
\hline $5.7 \leqq F_{1} \leqq 7.4$ & $7.1 \leqq F_{1} \leqq 13$ \\
\hline $1.0 \leqq h_{d} / h_{2} \leqq 4.2$ & $1.0 \leqq h_{d} / h_{2} \leqq 6.0$ \\
\hline $4.0 \mathrm{~cm} \leqq d_{c} \leqq 8.0 \mathrm{~cm}$ & $4.0 \mathrm{~cm} \leqq d_{c} \leqq 8.3 \mathrm{~cm}$ \\
\hline$B=40 \mathrm{~cm}$ & $B=40 \mathrm{~cm}, 50 \mathrm{~cm}$ \\
\hline$H_{\text {dam }}=41.0,152.5 \mathrm{~cm}$ & $H_{\text {dam }}=82.0,247.3 \mathrm{~cm}$ \\
\hline
\end{tabular}

$$
\begin{aligned}
& B: \text { 水路幅 } \quad d_{c} \text { : 限界水深 } \\
& h_{d} \text { :下流水深 } H_{d a m} \text { ダム高 }
\end{aligned}
$$

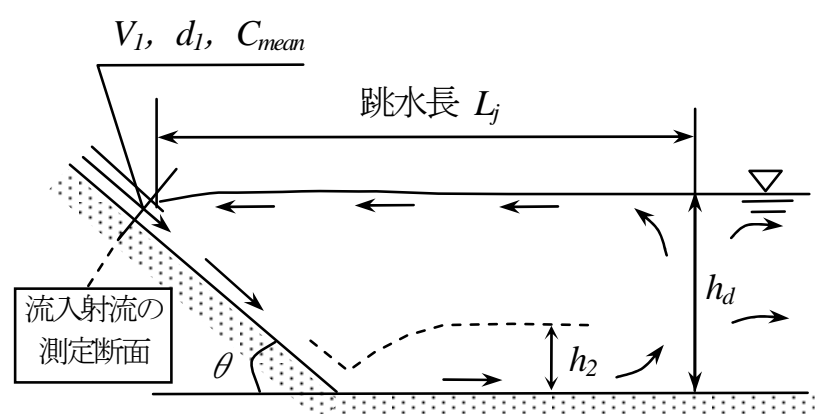

図-1 記号の定義

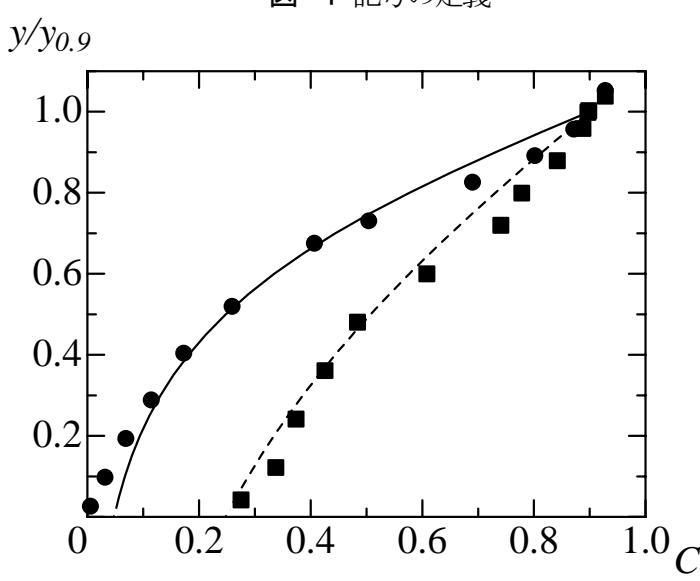

実験值 $\quad\left(0.300<R_{e} \times 10^{-5}<3.00\right)$

- $\quad \therefore=30^{\circ} C_{\text {mean }}=0.38$

- $\quad \theta=55^{\circ} C_{\text {mean }}=0.55$

Chanson (1996) $\left(4.52<R_{e} \times 10^{-5}<61.8\right)$

$$
-: C_{\text {mean }}=0.38
$$

図一2 流入射流における気泡混入率の分布

\section{3. 流入射流の気泡混入量による跳水長の変化}

水路傾斜角度 $\theta=30^{\circ}, 55^{\circ}$ における $C_{\text {mean }} / C_{M}$ による跳 水長 $L_{j} h_{2}$ の変化を図一 3 に示寸. ここで， $C_{M}$ はレイノ ルズ数 $R_{e}$ が $30000 \lesssim R_{e} \lesssim 300000$ の範囲における $C_{\text {mean }}$ の最大值を示している(本実験において $\theta=30^{\circ}$ の場合, $C_{M}=0.38, \theta=55^{\circ}$ の場合, $\left.C_{M}=0.55\right)$. また, 跳水長 $L_{j}$ は跳 水始端から逆流が常に観察されなくなった断面までの水 平距離として定め, 跳水終端では流速が十分減衰してい 
ることを流速測定の結果から確認している ${ }^{33,6.9}$

図一3に示されるように，流入射流の断面平均された 気泡混入率が $0 \leqq C_{\text {mean }} / C_{M}<0.6$ の範囲では, 相対下流水 深 $h_{d} / h_{2}$ が大きくなるにつれて広範囲に逆流を伴う循環 流が形成され， $L_{j} / h_{2}$ は大きくなる．この場合，跳水内部 の主流に気泡が混入されにくく, 主流の巻き上げに対す る浮力効果が小さくなったものと考えられる.

$0.6<C_{\text {mean }} / C_{M} \leqq 0.8$ の範囲では，相対下流水深 $h_{d} / h_{2}$ が 大きくなるにつれて, $C_{\text {mean }} / C_{M}$ の増加に伴う $L_{j} / h_{2}$ の減少 率が大きくなる．この場合， $C_{\text {mean }} / C_{M}$ が大きくなるにつ れて，跳水内部の主流に気泡が混入されや寸くなる．特 に，下流水深が大きいほど気泡の浮力効果によって，跳 水長が短くなるものと考えられる.

$0.8<C_{\text {mean }} / C_{M} \leqq 1.0$ の範囲では, 相対下流水深 $h_{d} / h_{2}$ の 大小によらず $L_{j} / h_{2}=5.7 \sim 6.0$ となり, 自由跳水長 ${ }^{2)}$ とほぼ 同じ值を示寸．この場合，跳水内部の主流に多量の気泡 が常に混入されている.このことから，主流の巻き上げ に対する浮力効果が大きく，下流水深の大小に関わらず 常に表面渦が形成されるようになったものと考えられる。

なお，水路傾斜角度 $\theta=30^{\circ}$ と $55^{\circ}$ との間では $C_{\text {mean }} / C_{M}$ による $L_{j} / h_{2}$ の違いは認められない．

流入射流の断面平均された気泡混入率 $C_{\text {mean }} / C_{M}$ および 相対下流水深 $h_{d} / h_{2}$ の変化を考慮し,$L_{j} / h_{2}$ の実験式を以 下に提案する。

$$
\left.\begin{array}{c}
L_{j} / h_{2}=\left(4.6-2.1 C_{\text {mean }} / C_{M}\right)\left(h_{d} / h_{2}-1\right)+5.7 \\
\left(0 \leqq C_{\text {mean }} / C_{M}<0.6\right) \\
L_{j} / h_{2}=16.8\left(0.8-C_{\text {mean }} / C_{M}\right)\left(h_{d} / h_{2}-1\right)+5.7 \\
\left(0.6 \leqq C_{\text {mear }} / C_{M}<0.8\right) \\
L_{j} / h_{2}=5.7 \sim 6.0 \quad\left(0.8 \leqq C_{\text {mear }} / C_{M} \leqq 1.0\right)
\end{array}\right\}
$$

なお，水路床から $y=y_{0.9}$ の位置までの跳水始端におけ る気泡混入率 $C$ および流速 $\bar{u}$ の測定結果》をを次式に代入 して単位幅流量 $q_{w}{ }^{\prime}$ が求められる.

$$
q_{w}=\int_{0}^{y_{0}, 9}(1-C) \bar{u} d y
$$

(5)式から得られた $q_{w}{ }^{\prime}$ と全幅堰によって測定された $q_{w}$ と が一致することを確認している. 寸なわち， $y_{0.9}$ を気泡混 入流の代表水深とすることによって連続の式 $q_{w}{ }^{\prime}=q_{w}$ を 満足する.

\section{4. 跳水上下流端の水深間の関係}

傾斜水路の跳水を対象に，跳水上下流端の水深間の関 係に対する流入射流およひ跳水部における気泡混入の影 響を明らかにするために，図一4に示される I，II断面間 の跳水部を検查部に選び，水路傾斜方向に運動量方程式
$L_{j} / h_{2} \quad-\cdots$ : 傾向線

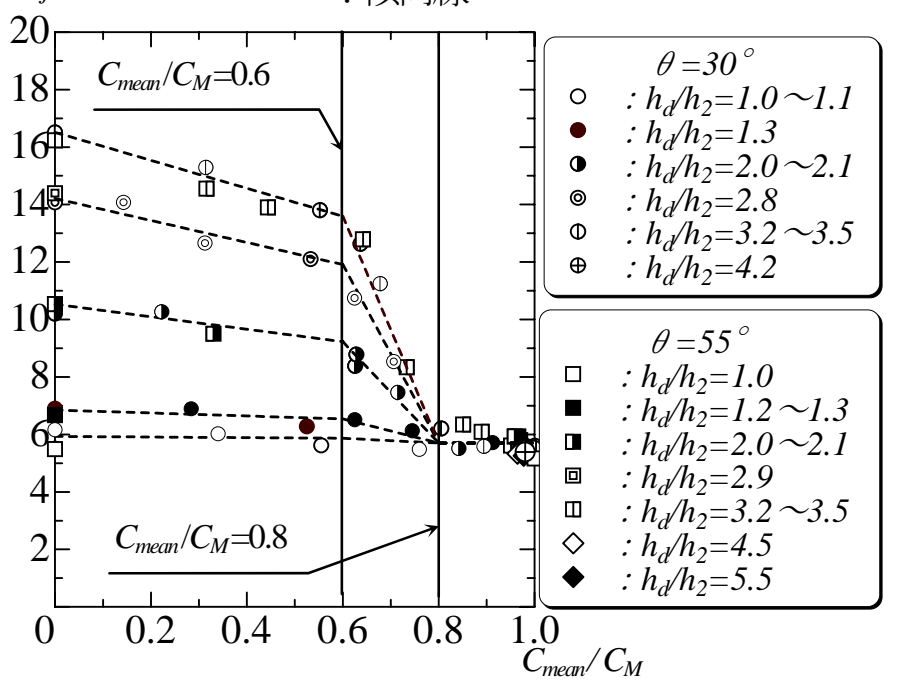

図-3 $C_{\text {mean }} / C_{M}$ による跳水長の変化



$F_{H}:$ 水路水平面上の水路底面に作用寸る全圧力

$P_{l}, P_{d}:$ 跳水上下流端断面に作用寸る全圧力

$W_{S}, W_{H}: \mathrm{I} \sim \mathrm{J}, \mathrm{J} \sim$ II断面までの質量力

図-4 記号の定義図

を適用すると(6)式が得られる．なお，流入射流およひ跳 水部の気泡混入率の変化を密度変化に置き換えて解析を 行っている. このとき, 検査部水路底面での壁面摩擦力, 検查面での Reynolds 応力による表面力および水表面での 表面張力を無視する．また，跳水部において気泡（気相） と水流 (液相) が一体となって運動するものと仮定する. さらに水路横断方向に対し水理量は変化しないものとす る. なお，(6)式は単位幅の水理量で示され, 記号は図一 4 に基づく.

$\rho_{w} q_{w}\left(\beta_{d} V_{d} \cos \theta-\beta_{I} V_{I}\right)$

$=\left(W_{S}\right) \sin \theta+\left(W_{H}-F_{H}\right) \sin \theta+P_{l}-P_{d} \cos \theta$

ここに, $\beta_{1}, \beta_{d}$ は跳水始端・終端での運動量補正係数 である. (6)式の各項について以下に示寸.

\section{(1) 質量力}

$W_{S}$ および $W_{H}$ は検査部において水路傾斜面上および氷 平面上の質量力を示し, 次式で示される. 


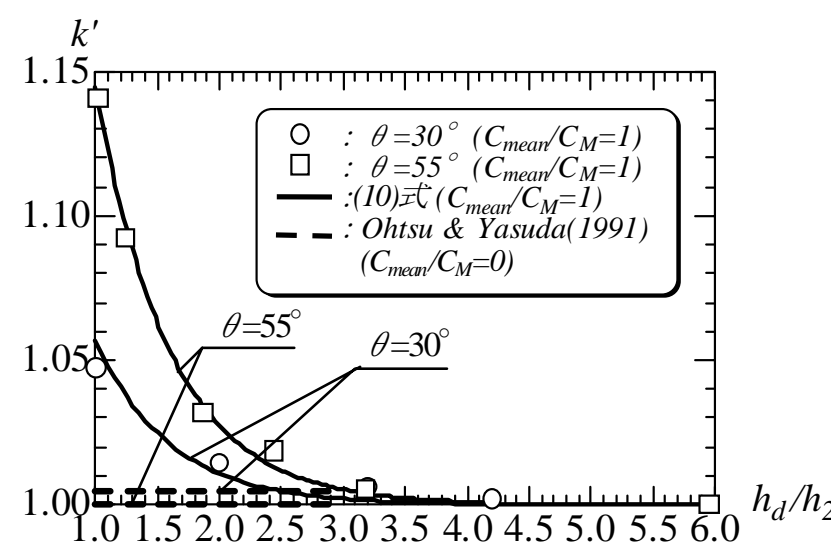

図一5 $h_{d} / h_{2}, \theta$ および $C_{\text {mean }} / C_{M}$ による $k^{\prime}$ 変化

$$
\begin{gathered}
W_{S}=S_{S}\left(W_{S}\right)_{w}=S_{S} \frac{\rho_{w} g}{2}\left\{y_{0.9}{ }^{2} \tan \theta+k^{\prime}\left(y_{0.9} / \cos \theta+h_{j}\right) \ell\right\} \\
W_{H}=S_{H}\left(W_{H}\right)_{w}=S_{H} \frac{\rho_{w} g}{2}\left\{k^{\prime}\left(h_{d}+h_{j}\right)\left(L_{j}-\ell\right)\right\} \\
h_{j}=\left(\ell \tan \theta+\frac{y_{0.9}}{\cos \theta}\right)+\left\{h_{d}-\left(\ell \tan \theta+\frac{y_{0.9}}{\cos \theta}\right)\right\} \frac{\ell}{L_{j}}
\end{gathered}
$$

ここで，k’は跳水始端から終端までの水面形を直線変化 するものとみなして算定した跳水部の体積と水面形の実 測から求めた跳水部の体積との比を示し, $\left(W_{S}\right)_{w}$ および $\left(W_{H}\right)_{w}$ は検査部において水面までを全て水とした場合の 水路傾斜面上および水平面上の質量力を示している. な お，本研究では $C=0.9$ となる位置を水面として定めてい る. また, $h_{j}$ は水路接合部の水路床から跳水始端と跳水終 端とを結んだ直線までの高さを示す(図ー4 参照).

$C_{\text {mean }} / C_{M}=1$ の場合における $k^{\prime}$ の変化を図一 5 に示す. なお, 図一 5 中の破線は $C_{\text {mean }} / C_{M}=0$ の場合の実験式 3$)$ を示してい る. $C_{\text {mean }} / C_{M}=1$ の場合, 跳水始端付近に多量の気泡が混 入し水面が上昇するため $C_{\text {mean }} / C_{M}=0$ の場合 ${ }^{3)}$ に比べ $k^{\prime}$ は 大きい值となる. また, $C_{\text {mean }} / C_{M}=1$ の場合, 相対下流水 深 $h_{d} / h_{2}$ の増加に伴い $k^{\prime}$ は小さくなり, 水路傾斜角度 $\theta$ 小 よび $C_{\text {mean }} / C_{M}$ によらず $k$ 'は 1 に近づく. $C_{\text {mean }} / C_{M}=1$ にお ける $k^{\prime}$ の実験式を以下に示す.

$$
k^{\prime}=1+10^{\left[-0.723 h_{d} / h_{2}+0.626 \tan \theta-1.02\right]}
$$

$S_{S}$ は跳水部における傾斜面上の実際の質量力と傾斜面 上の跳水部を全て水とみなして算定した質量力との比で あり， $S_{H}$ は跳水部における水平面上の実際の質量力と水 平面上の跳水部を全て水とみなして算定した質量力との 比を示し, 次式で定義する.

$$
\begin{aligned}
& S_{S}=1-\frac{1}{\ell / L_{j}} \int_{0}^{\ell / L_{j}}\left(C_{o}\right) d\left(\frac{X}{L_{j}}\right) \\
& S_{H}=1-\frac{1}{1-\ell / L_{j}} \int_{\ell / L_{j}}^{l}\left(C_{o}\right) d\left(\frac{X}{L_{j}}\right)
\end{aligned}
$$

ここに, $C_{o}$ は跳水内部の各鉛直測定断面において $y=0$ か ら $y=y_{0.9}$ までの平均された気泡混入率, $X$ は跳水始端か

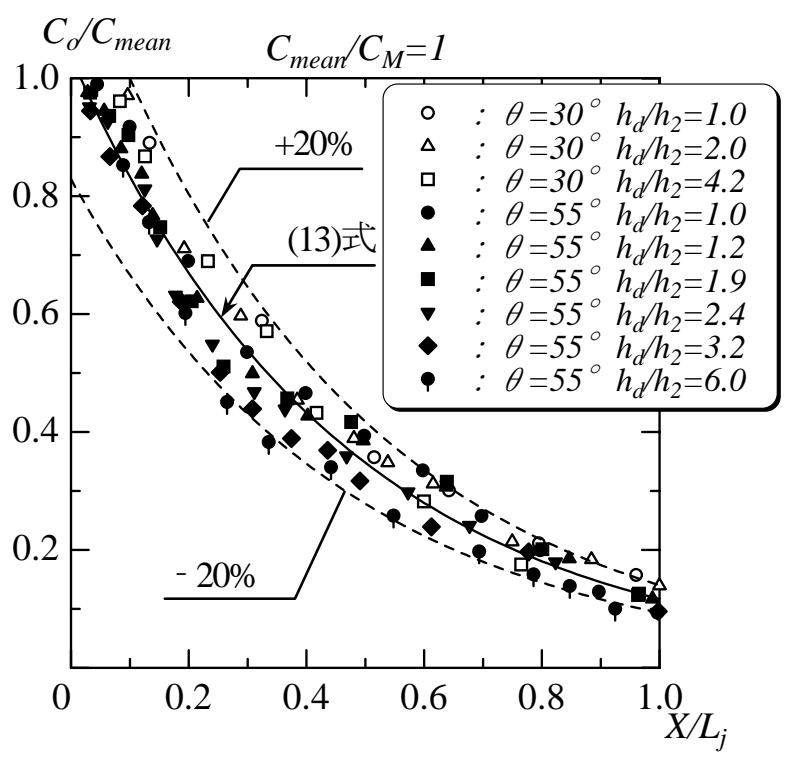

図一6 跳水内部の気泡混入率の変化 $\left(C_{\text {mean }} / C_{M}=1\right)$

らの水平距離を表している. $C_{\text {mean }} / C_{M}=1$ における跳水内 部の気泡混入率 $C_{o} / C_{\text {mean }}$ の変化 ${ }^{6}$ を図一6 に示す. 図一6 に示されるように, $C_{o} / C_{\text {mean }}$ は水路傾斜角度 $\theta$, 相対下流 水深 $h_{d} / h_{2}$ によらず $X / L_{j}$ によって整理される. $X / L_{j}$ による $C_{o} / C_{\text {mean }}$ の変化を表す実験式を以下に示す.

$$
\frac{C_{o}}{C_{\text {mean }}}=e^{0.0353-2.18 \frac{X}{L_{j}}} \quad\left(\frac{C_{\text {mean }}}{C_{M}}=1\right)
$$

\section{(2) 水路水平部における跳水中の底面に作用する全圧力}

$F_{H}$ は水路水平部における跳水中の水路底面に作用する 全圧力を示し, 次式で表される.

$$
F_{H}=r W_{H}
$$

ここで, $r$ は水路水平部の検査部内の底面に作用する実際 の全圧力と静水圧と仮定した場合の全圧力との比である. $C_{\text {mean }} / C_{M}=1$ の場合における $r$ の変化を図一7示す. なお, 図一7 中の破線は $C_{\text {mean }} / C_{M}=0$ の場合の実験式 ${ }^{3), 10)}$ を示し ている. $C_{\text {mean }} / C_{M}=1$ の場合, $C_{\text {mean }} / C_{M}=0$ の場合に比べ $r$ は大きい值となる. また, $C_{\text {mean }} / C_{M}=0$ および 1 の場合と もに $h_{d} / h_{2}$ の増加に伴い $r$ は減少し 1 に近づく. $C_{\text {mean }} / C_{M}$ $=1$ における $r$ の実験式を以下に示す.

$$
r=1+10^{\left[-0.446 h_{d} / h_{2}+\{\ln (\tan \theta-0.3)-1.28\} / 2.25\right]}
$$

\section{(3) 跳水始端・終端での全圧力}

$P_{1}, P_{d}$ は跳水始端断面および終端断面での単位幅当た りの全圧力を示し，次式で表される.

$$
\begin{aligned}
& P_{l}=\rho_{w} g \cos \theta \int_{0}^{y_{0.9}} \int_{y}^{y_{0.9}}(1-C) d y d y \\
& =\lambda_{1} \frac{\rho_{w} g}{2} d_{1}^{2} \cos \theta
\end{aligned}
$$






図一7 $h_{d} / h_{2}, \theta$ および $C_{\text {mean }} / C_{M}$ による $r$ の変化

$$
\begin{gathered}
\lambda_{l}=1+\frac{2 C_{\text {mean }}}{1-C_{\text {mean }}}+\frac{2 \iint_{0}^{l}\left(\int_{0}^{y^{+}} C d y^{+}\right) d y^{+}}{\left(1-C_{\text {mean }}\right)^{2}} \quad\left(y^{+}=\frac{y}{y_{0.9}}\right) \\
P_{d}=\lambda_{d} \frac{\rho_{w} g}{2} h_{d}{ }^{2}
\end{gathered}
$$

ここに， $\lambda_{1}$ は跳水始端での水の夕に換算した水深 $d_{1}$ およ び水の密度 $\rho_{w}$ で表示したときの全圧力の補正係数であ る. $C_{\text {mean }}$ による $\lambda_{1}$ の変化を図一 8 に示寸. 図に示される ように， $C_{\text {mean }}$ が増加するにつれて $\lambda_{1}$ は増加する.

$\lambda_{d}$ は跳水終端䉼面における全圧力の補正係数を示して いる. 跳水終端断面では気泡混入されず静水圧分布して いることから $\lambda_{d}=1.0$ である.

\section{(4) 跳水始端 • 終端での運動量}

跳水始端での運動量に示される $\beta_{1}$ は跳水始端での水 のみに換算した水深 $d_{1}$, 水のみの単位幅流量 $q_{w}$, 水の 密度 $\rho_{W}$ で表示したときの運動量補正係数であり, 次式で 示される.

$$
\beta_{1}=\frac{\int_{0}^{y_{0.9}} \rho \bar{u}^{2} d y}{\rho_{w} q_{w} V_{w}}=\frac{\int_{0}^{y_{0.9}}(1-C)\left(\frac{\bar{u}}{V_{0.9}}\right)^{2} d y}{\left[\int_{0}^{y_{0.9}}(1-C)\left(\frac{\bar{u}}{V_{0.9}}\right) d y\right]^{2}} d_{1}
$$

ここで $\rho, V_{w}$ はそれぞれ $\rho=(1-C) \rho_{w}, V_{w}=q_{w} / d_{1}$ を示す。 実験的に求められた気泡混入率 $C$ および流速 $\bar{u}$ を(18) 式に代入して $\beta_{1}$ を求めると， $C_{\text {mean }}$ の変化に関わらず $\beta_{1}=1.03 \sim 1.05$ となり（図-8）, $\beta_{1} \doteqdot 1.0$ とみなせる. な お， 跳水始端の流速分布は指数則 ${ }^{7} \bar{u} / V_{0.9}=\left(y / y_{0.9}\right)^{1 / 6}\left(V_{0.9}\right.$ は $y=y_{0.9}$ のときの $\left.\bar{u}\right)$ で近似できるものとしている. 跳水 終端断面での運動量補正係数 $\beta_{d}$ についは, 流速分布の 実測值から， $\beta_{d}=1.0$ とみなせることを確認している.

(7)，(8)，(14)，(16)，(17)を(6)式に代入し整理すると， 次式のように無次元表示される.

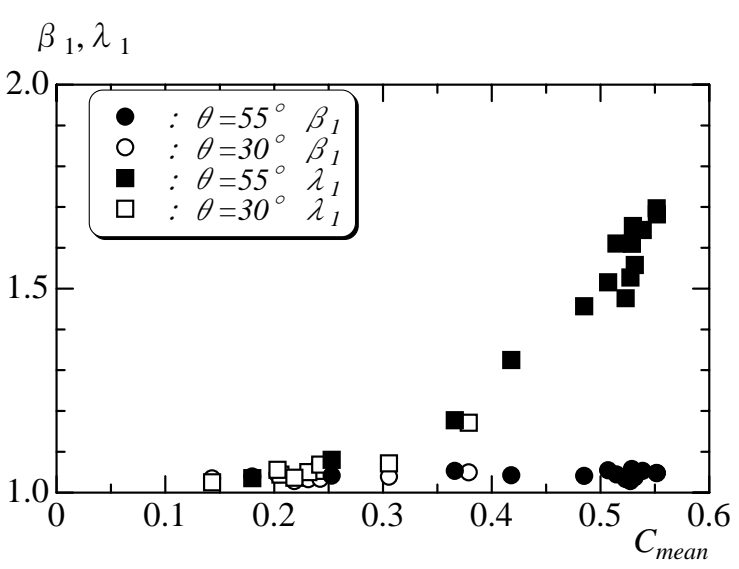

図-8 $C_{\text {mean }}$ の変化に対する $\beta_{1}, \lambda_{1}$ の変化

$$
\begin{aligned}
& \left(\frac{h_{d}}{d_{l}}\right)^{3}-\left[S_{S}\left\{\frac{\tan \theta}{\left(1-C_{\text {mean }}\right)^{2}}+k^{\prime}\left(\frac{1}{\left(1-C_{\text {mean }}\right) \cos \theta}+\frac{h_{j}}{d_{l}}\right) \frac{\ell}{d_{l}}\right\} \tan \theta\right. \\
& \left.+S_{H}(1-r)\left\{k^{\prime}\left(\frac{h_{j}}{d_{l}}+\frac{h_{d}}{d_{l}}\right)\left(\frac{L_{j}}{d_{l}}-\frac{\ell}{d_{l}}\right)\right\} \tan \theta+\lambda_{l}+2 F_{I}^{2}\right]\left(\frac{h_{d}}{d_{l}}\right) \\
& +2 F_{I}^{2} \cos \theta=0
\end{aligned}
$$

なお， $\ell / d_{1}, F_{1}, \theta$ および $C_{\text {mean }}$ を(19)式に代入して $h_{d} / d_{1}$ を算出する際に， $\lambda_{1}$ の值を 1 と仮定して計算した場合と 実験值の $\lambda_{1}$ の值を用いて計算した場合との差は $h_{d} / d_{1}$ の 計算值の $1 \%$ 以内であるため $\lambda_{1}=1.0$ としている.

$S_{S}, S_{H}, k, r$ の実験式および $L_{j} / h_{2} \approx 5.7$ を(19)式に代 入することによって $C_{\text {mean }} / C_{M}=1$ における跳水上下流端の 水深間の関係(20)式が得られる.

$$
\ell / d_{l}=f\left(h_{d} / d_{l}, F_{1}, \theta, C_{\text {mean }} / C_{M}\right)
$$

(19)式から算出された $h_{d} / d_{l}$ を $\left(h_{d} / d_{1}\right)_{c a l}$ とし, 実験的に得 られた $h_{d} / d_{1}$ を $\left(h_{d} / d_{1}\right)_{e x p}$ として比較すると, 誤差 $\left[\mid\left(h_{d} / d_{1}\right)_{e x p}\right.$ $\left.-\left(h_{d} / d_{1}\right)_{\text {cal }} \mid /\left(h_{d} / d_{1}\right)_{\text {exp }} \times 100(\%)\right]$ は 5\%以内となる(図一9).

$\theta=30^{\circ}, 55^{\circ}$ を対象に $C_{\text {mean }} / C_{M}=0$ および 1 における跳 水上下流端の水深間の関係の比較を図一10 に示寸. 図中 破線は $C_{\text {mean }} / C_{M}=0$ の場合 ${ }^{3)}$, 実線は $C_{\text {mean }} / C_{M}=1$ の場合 における水深間の関係を示している. ただし, $C_{\text {mean }} / C_{M}=$ 0 でかつ水路傾斜角度 $\theta>23^{\circ}$ の場合, $h_{d} / h_{2}>3.0$ の範囲 で表面渦の形成が認められないので ${ }^{3)}, \quad C_{\text {mean }} / C_{M}=0$ の 場合, $1.0 \leqq h_{d} / h_{2} \leqq 3.0$ の範囲の計算値を示している.

図一10に示されるように与えられた $\theta, F_{1}$, および $h_{d} / d_{1}$ に対して $C_{\text {mean }} / C_{M}=1$ の $\ell / d_{1}$ の值は $C_{\text {mean }} / C_{M}=0$ $=/ d_{1}$ の 值に比べて最大 $9.5 \%$ 大きくなる. これは跳水部に気泡が 混入されたことによって, 跳水始端近くで体積が増加す るため, $C_{\text {mean }} / C_{M}=0$ の場合よりも跳水始端位置が上流側 に位置したためと考えられる.

また, $\theta=55^{\circ}$ の場合, 計算結果から $0 \leqslant \ell / d_{1} \lesssim 2$ の範 囲で一つの相対下流水深 $h_{d} / d_{1}$ に対して二つの $\ell / d_{1}$ が存 在する. 跳水始端が水路接合部近くになると, 跳水の位 置が変動することが実験的に確かめられている，与えら 


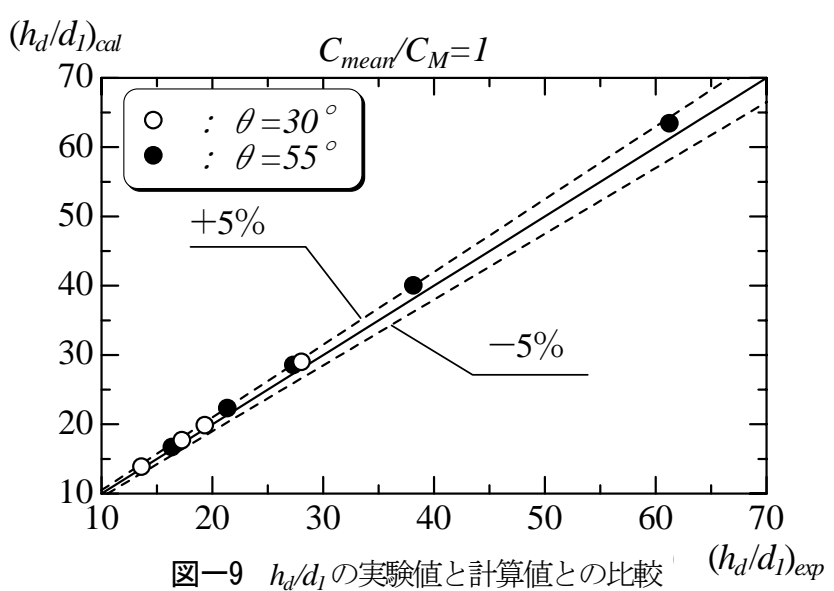

れた $h_{d} / d_{1}$ に対する二つの $\ell / d_{1}$ の存在からこの現象を説 明することができる. 同一の相対下流水深 $h_{d} / d_{l}$ に対して $\ell / d_{l}$ の值が一つの解をもつ範用では $\left(\ell / d_{l}>2\right)$ 水路傾斜面 上に跳水始端が位置し，始端の位置は安定していること が確認されている.

\section{5. まとめ}

水路傾斜角度 $\theta=30^{\circ}$ および $55^{\circ}$ の傾斜水路において射 流から常流入遷移寸る流れを対象とし，流入射流の気泡 混入量による跳水長の変化について実験的に検討した. また，流入射流およひ跳水部の気泡混入の影響を考慮し た運動量方程式を用いて跳水上下流端の水深間の関係に ついて検討した. 得られた結果を以下にまとめる.

(1) 流入射流の断面平均された気泡混入率 $C_{\text {mean }} / C_{M}$ によ る跳水長 $L_{j} / h_{2}$ の変化について広範囲な実験条件のも とで検討した結果， $0 \leqq C_{\text {mean }} / C_{M}<0.6$ の場合，下流 水深の増加に伴い跳水長が長くなり, $C_{\text {mean }} / C_{M}$ によ る変化が小さいことを示した. また, $0.6<C_{\text {mean }} / C_{M} \leqq$ 0.8 では $C_{\text {mean }} / C_{M}$ の影響を受けて $L_{j} / h_{2}$ は大きく減 少し, $0.8<C_{\text {mean }} / C_{M} \leqq 1.0$ では $L_{j} / h_{2}=5.7 \sim 6.0$ となり 自由跳水長とほぼ同じ值を示すことを明らかにした。 さらに, $C_{\text {mean }} / C_{M}$ および $h_{d} / h_{2}$ の変化による $L_{j} / h_{2}$ の 実験式を提案した。

(2) 傾斜水路における跳水を対象に運動量方程式を適用 し，質量力，底面圧力，跳水始端・終端での全圧力 および運動量の各項に対して気泡混入の影響を考慮 した跳水上下流端の水深間の関係を示した．また， 与えられた $\theta, F_{l}$, および $\ell / d_{l}$ に対して, 相対下流 水深 $h_{d} / d_{1}$ が予測されることを明らかにした.

(3) 与えられた $\theta, F_{l}$, および $h_{d} / d_{l}$ に対して $C_{\text {mean }} / C_{M}=1$ の場合, 跳水部に気泡が混入されたことによって跳 水始端近くで体積が増加するため, $C_{\text {mean }} / C_{M}=0$ の場 合よりも跳水始端位置が上流側に位置することを明 らかにした。 ld $\mathrm{d}_{1} \quad F_{1}=10$

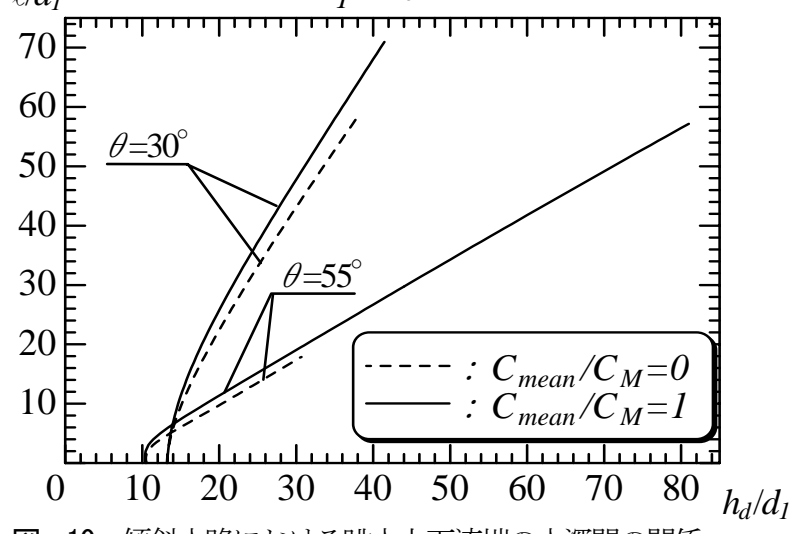

図一10 傾斜水路における跳水上下流端の水深間の関係

以上のことから，傾斜水路における跳水長およひ跳水上 下流端の水深間の関係に対する気泡混入射流の影響を明 確にし，順傾斜式水吒きにおいて流入射流の気泡混入を 考慮した減勢工の水工設計が可能であることを見出した.

\section{参考文献}

1) Rajaratnam, N.: Hydraulic Jumps, Advances in Hydroscience Vol.4, Chow, V.T. ed., Academic Press, New York, pp.197-280, 1967.

2) Ohtsu, I., Yasuda, Y., and Awazu, S.: Free and Submerged Hydraulic Jump in Rectangular Channels, Report 35, Research Institute of Science and Technology, Nihon University, pp.1-50, 1990.

3) Ohtsu, I. and Yasuda, Y.: Hydraulic Jump in Sloping Channels, Journal of Hydraulic Engineering, ASCE, Vol.117, No.7, pp.905-921, 1991.

4) W. H., Hager. : Energy Dissipators and Hydraulic Jump, Water Science and Technology Library, Vol.8, KLUWER, Dordrecht, 1992.

5) 安田、高橋、小林、大津: 傾斜水路の跳水特性に対寸る空気 混入射流の影響, 水工学論文集, 土木学会,第 46 巻, pp.601-605, 2002.

6) 小林, 安田, 大津: : 傾斜水路の跳水特性に対寸る気泡混入 射流の影響, 水工学論文集,士木学会,第 49 巻, pp.823-828, 2005.

7) Chanson, H.: Air Bubble Entrainment in Free surface Turbulent Shear Flows, Academic Press, New York, 1996.

8) Yasuda, Y. and Ohtsu, I.: Flow Resistance of Skimming Flows in Stepped Channels, Proceeding of 28th IAHR Congress, Graz, Austria, Session of B14 (CD-ROM), 1999.

9) Ohtsu, I., Yasuda, Y., and Takahashi, M.,: Flow Characteristics of Skimming Flows in Stepped Channels, Journal of Hydraulic Engineering, ASCE, Vol.30, No.9, pp.860-869, 2004.

10) Ohtsu, I. and Yasuda, Y.: Discussion of B-Jump in Sloping Channel, Journal of Hydraulic Research, IAHR, Vol.28, No.1, pp.105-119, 1990.

(2005.9. 30 受付) 